\title{
INFLUENCE OF GREEN MANURES ON EPIEDAPHIC MACROFAUNA IN CERRADO/PANTANAL ECOTONE
}

\author{
INFLUÊNCIA DE ADUBOS VERDES SOBRE A MACROFAUNA EPIEDÁFICA NO \\ ECÓTONO CERRADO/PANTANAL
}

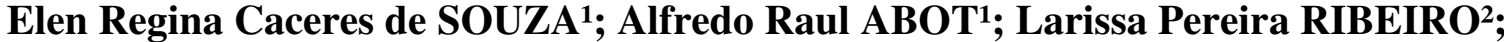 Francisco Eduardo TORRES'; Paulo Eduardo TEODORO ${ }^{3}$}

1. Universidade Estadual do Mato Grosso do Sul, Unidade Universitária de Aquidauana, Aquidauana, MS, Brasil; 2. Universidade Federal de Viçosa, Viçosa, MG, Brasil; 3. Universidade Federal do Mato Grosso do Sul, Campus de Chapadão do Sul, Chapadão do Sul, MS, Brasil. eduteodoro@ hotmail.com.

\begin{abstract}
The aim of this study was to determine the similarity between nine species of green manure regarding the occurrence of epiedaphic macrofauna. The experiment was conducted during the months of August 2014 to July 2015 at the Crop Science sector of the State University of Mato Grosso do Sul, Unit of Aquidauana. Treatmentes evaluated were: Canavalia ensiformes, Dolichos lablab, Mucuna pruriens, Mucuna aterrima, Crotalaria spectabilis, Crotalaria juncea, Crotalaria ochroleuca, Cajanus cajan, Cajanus cajan and two control (fallow area and native vegetation). Experimental design was completely randomized with two replications. Each plot consists of 10 lines with $4.5 \mathrm{~m}$ long. Epiedaphic macrofauna inhabiting the interphase between the vegetation cover and the soil surface was collected weekly by the Pitfall model. Individuals collected in all green manure species in the same month were added and subjected to cluster analysis. The months of September and October composed group 2 due to higher averages of epiedaphic macrofauna individuals. The month of July had the highest number of individuals from Isoptera order, composing the group 3. The month of November was in which was collected the greatest number of individuals from Hymenoptera order, which has allocated this month in group 4. The others months of the year formed the group 1, indicating that the region climatic conditions in this period do not affect significantly the distribution of epiedaphic macrofauna individuals.
\end{abstract}

KEYWORDS: Cluster analysis. Pitfall. Temporal variability.

\section{INTRODUCTION}

Fertilization is a practice used to provide organic matter and nutrients for plants, which enables the chemical fertilizers and the production costs reduction (BUZINARO et al., 2009). Its function is to incorporate organic matter, such as root exudates, root and leaf biomass and organic acids to the soil (DELARMELINDA et al., 2010).

The presence of a dead cover on the soil surface stimulates the soil fauna, the roots and the soil microflora, keeping its balance by decreasing degradation (LAVELLE; SPAIN, 2001). Organisms in the soil macrofauna, which include Annelida and Coleoptera, have a body diameter of between 2 to $20 \mathrm{~mm}$. They have great mobility and play an important role both in the transport of materials due to the fact that they make nests and burrows, and also for burrowing that reach variable depths and providing fragmentation of plant residue and its redistribution. (SWIFT et al., 1979). According to Barros et al. (2003), the main macrofauna members they are Oligochaeta, Formicidae and Isoptera.

Macrofauna has different effects on processes related to soil fertility, such as the regulation of microbial populations responsible for humification and mineralization (LAVELLE et al., 1997). Despite the importance of the soil macrofauna, few studies to evaluate the effects of green manure management on these organisms and the role of cover plants used on the dynamics of soil invertebrate communities on the balance and functioning of ecosystems, have been performed especially in the Cerrado biome (BLANCHART et al. 2006).

Blanchart et al. (2006) report that several studies have highlighted the benefits of using green manure, especially with legume species on soil properties and sustainability. However, the mechanisms responsible for these benefits are not yet fully known. Thus, this study aimed to determine the similarity between nine species of green manure regarding the occurrence of epiedaphic macrofauna.

\section{MATERIAL AND METHODS}

The trial was conducted at Sector of Crop Science of the State University of Mato Grosso do Sul (UEMS), in Aquidauana-MS, between August 2014 and July 2015. The climate, according to 
Köppen-Geiger classification, is Aw (Warm Humid Tropical), with rainy summers and dry winters, with average annual rainfall of $1,250 \mathrm{~mm}$ and average temperature of $26^{\circ} \mathrm{C}$. The region is composed of native vegetation, large areas of pasture (cultivated grasses) and small orchards.

Treatmentes evaluated were: Canavalia ensiformes, Dolichos lablab, Mucuna pruriens, Mucuna aterrima, Crotalaria spectabilis, Crotalaria juncea, Crotalaria ochroleuca, Cajanus cajan, Cajanus cajan cv "fava larga" and two control (fallow area and native vegetation). When the cover plants reached flowering, it were cut and the material was distributed on the ground. The maize sowing was carried out in no-till system 21.12.2014 (beginning of rainy season). The experimental design was completely randomized, with two replications. Each experimental unit (plot) consisted of 10 lines with $4.5 \mathrm{~m}$ long. The spacing adopted for each species was $0.5 \mathrm{~m}$ between rows.

Epiedaphic macrofauna inhabiting the interphase between the vegetation cover and the soil surface was collected weekly by the Pitfall model. In the first trial, they were installed two pitfalls in each experimental unit (portion), being carried out weekly collection from August 2014 to July 2015. As a reference were installed two pitfalls on fallow soil, without vegetation cover, outside the plots boundary and two on native forest area distant approximately $300 \mathrm{~m}$ from the trial.

The pitfall consisted plastic containers with a capacity of $500 \mathrm{~mL}$ and $12 \mathrm{~cm}$ in diameter, which were buried up to ground level and inside was added water to $1 / 3$ of its capacity and $10 \mathrm{~mL}$ of detergent to break the surface tension of the organisms and allow them to be deposited in the container bottom. In order to prevent organisms deterioration, was added $10 \mathrm{ml}$ of formaldehyde $4 \%$. The organisms were removed from the pitfalls every seven days and the liquid was renewed. Pitfalls remained active until the end of the trial, after maize harvest. The material recorded with the date and depth of collection and treatment code was sent to the entomology laboratory of the Unit. The macrofauna organisms were screened on trays, clustered by Class or Order, quantified and reported as the number of specimens/pitfall/day. Data were recorded in spreadsheets for statistical analysis.

Data were organized in two ways, the first was the sum of the individuals from the same Order collected over the months (August 2014 to July 2015) according to each green manure species. In the second form, individuals from the same Order collected in green manure species were added, separating according to each month of collection.
Cluster analysis were performed in order to verify the similarity between green manure species regarding the occurrence of epiedaphic macrofauna. Ward's agglomerative algorithm was used, having as dissimilarity measure the Euclidean distance (EVERITT; DUNN, 1991).

Ward's algorithm form groups, minimizing the dissimilarity or minimizing the total sums of squares within groups, also known as sum of square deviations (SSD). In each step of the procedure, groups are formed, so that the resulting solution has the lowest SSD within groups. At these stages, the clusters of all possible pairs of groups are considered and the two resulting in lower increase of SSD are clustered until all the groups form a single, gathering all individuals (EVERITT; DUNN, 1991). All analyzes used the Statistica software (STATSOFT, 2005).

\section{RESULTS AND DISCUSSION}

Orthoptera and Hymenoptera were the most abundant Orders with an average of 134 and 182 individuals per legume species, respectively (Table 1). Mucuna pruriens was the species with the highest occurrence of epiedaphic macrofauna, especially Orthoptera and Hymenoptera. According to Marasas et al. (2001), vegetable waste provided by Mucuna pruriens are the main source of food and habitat for most species of invertebrates that inhabit the soil. This has made this legume species constituted separately the group 2 of similarity between green manures (Figure 1).

Regarding the highest occurrence of a epiedaphic fauna in a particular vegetation cover, Almeida (2012) suggests a link between Orthoptera and leguminous plants, since the author found a higher occurrence of individuals of this order in areas cultivated with the vetch crop (Lathynus sativus L.). The same applies to the order Hymenoptera, which has a preference for living and dense covers (MENDES et al., 2011), likewase the case of the Mucuna pruriens.

Cajanus cajan cv "fava larga" was the most common species in between the individuals from Isoptera, constituting the group 3. Among the insects, termites are one of the most important taxa in terms of local relative abundance (PANIZZI; PARRA, 2009). According to Oliveira et al. (2004), results obtained for increasing termite individuals are not related to the chemical characteristics of the soil, but to the availability of organic matter, probably caused by this species. According to Baretta (2007), individuals from Isoptera degrade organic matter with a high $\mathrm{C}$ : $\mathrm{N}$ ratio, favored by its 
enzymatic ability to degrade compounds that are more complex. Lastly, there are the other leguminous species not highlighted by the specific occurrence of any Order, being all of them clustered in group 1 due to the similarity amongst them.

Another hypothesis for the increased occurrence of fauna in a soil covered by a particular plant species is the quality of food. The form of the groundcover plant, fresh or decomposition matter, which will be the food, , can be decisive in the composition and activity of the soil organisms. Within the soil organisms, for instance, the chewers prefer food with higher water and nitrogen content (PARRA et al., 2009).

Table 1. Number of epiedaphic macrofauna individuals depending on the species of green manure grown between August 2014 and July 2015. Aquidauana, MS.

\begin{tabular}{|c|c|c|c|c|c|c|c|c|c|c|c|c|c|c|}
\hline $\begin{array}{l}\text { Leguminous } \\
\text { species }\end{array}$ & 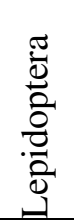 & $\begin{array}{l}\frac{\pi}{0} \\
\frac{\tilde{0}}{0} \\
\frac{0}{0} \\
ن\end{array}$ & 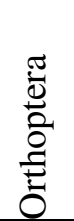 & $\begin{array}{l}\frac{\pi}{0} \\
\stackrel{0}{0} \\
0\end{array}$ & 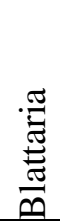 & 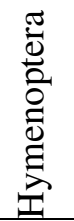 & $\begin{array}{l}\frac{\pi}{0} \\
\stackrel{0}{0} \\
0 \\
0\end{array}$ & 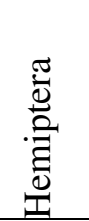 & $\begin{array}{l}\frac{\pi}{0} \\
\frac{0}{0} \\
\frac{0}{3} \\
\tilde{U}\end{array}$ & $\begin{array}{l}\frac{\pi}{0} \\
\frac{0}{0} \\
\frac{0}{0} \\
0\end{array}$ & 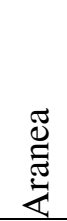 & $\begin{array}{l}\tilde{0} \\
\stackrel{0}{0} \\
\stackrel{0}{0} \\
\tilde{0} \\
\tilde{0}\end{array}$ & 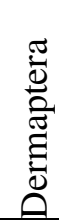 & 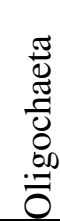 \\
\hline C. cajan & 20 & 69 & 131 & 37 & 55 & 149 & 19 & 60 & 4 & 11 & 23 & 1 & 0 & 0 \\
\hline $\begin{array}{l}\text { C. cajan cv. } \\
\text { fava larga }\end{array}$ & 23 & 53 & 85 & 12 & 62 & 92 & 554 & 53 & 6 & 15 & 23 & 1 & 0 & 0 \\
\hline C. ochroleuca & 73 & 67 & 112 & 49 & 41 & 176 & 82 & 89 & 7 & 14 & 22 & 1 & 1 & 0 \\
\hline C. spectabilis & 34 & 85 & 135 & 43 & 36 & 178 & 9 & 122 & 8 & 16 & 39 & 3 & 0 & 0 \\
\hline C. juncea & 24 & 59 & 180 & 36 & 52 & 113 & 19 & 93 & 8 & 11 & 27 & 1 & 0 & 0 \\
\hline D. lablab & 17 & 95 & 120 & 19 & 71 & 182 & 15 & 63 & 7 & 17 & 27 & 0 & 0 & 0 \\
\hline M. aterrima & 15 & 92 & 194 & 32 & 61 & 142 & 14 & 31 & 5 & 12 & 22 & 0 & 0 & 0 \\
\hline M. puriziens & 25 & 96 & 208 & 25 & 71 & 558 & 16 & 25 & 8 & 11 & 27 & 2 & 1 & 0 \\
\hline C. ensiformes & 14 & 60 & 121 & 23 & 82 & 109 & 13 & 21 & 0 & 9 & 10 & 2 & 1 & 0 \\
\hline Fallow area & 19 & 75 & 152 & 25 & 53 & 111 & 31 & 44 & 2 & 13 & 17 & 1 & 0 & 0 \\
\hline $\begin{array}{l}\text { Native } \\
\text { vegetation }\end{array}$ & 4 & 67 & 41 & 9 & 23 & 189 & 3 & 5 & 4 & 1 & 30 & 6 & 2 & 0 \\
\hline Mean & 24 & 74 & 134 & 28 & 55 & 182 & 70 & 55 & 5 & 12 & 24 & 2 & 0 & 0 \\
\hline
\end{tabular}

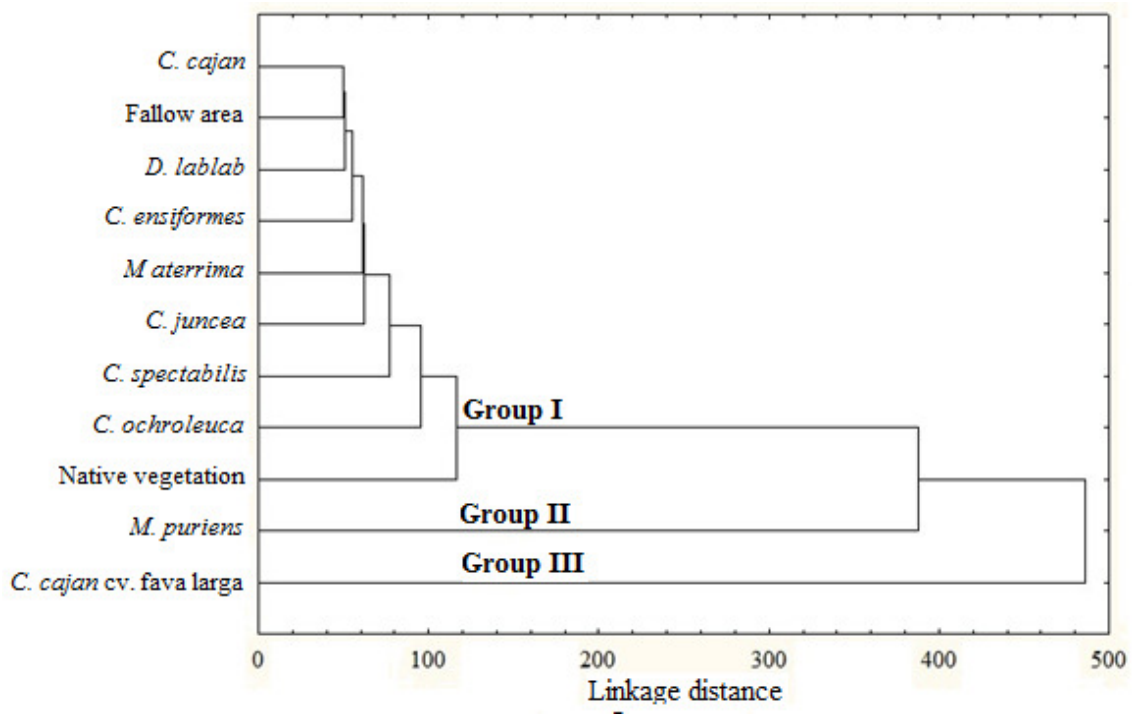

Figure 1. Cluster dendrogram between leguminous species based on the number of epiedaphic macrofauna individuals, from August 2014 to July 2015, em Aquidauana MS

The highest averages for the number of epiedaphic macrofauna individuals (Table 2) were checked in September, October, November and July Thus, these months formed group 2, generated by 
the cluster analysis (Figure 2). Soil organisms can be influenced by weather conditions, which explains the occurrence of soil fauna as an indicator of environmental changes (ASSAD; LACERDA, 1995).

Moço et al. (2005) report that the soil fauna is sensitive both to changes in temperature and humidity as well as the availability of food. Moreover, the composition of the cover, such as a larger content of water, carbon, and nitrogen can select organisms with specific nutritional preferences (PARRA et al., 2009). Possibly, the cluster occurred due to the effect of the vegetation decomposition. The increased availability of energy and nutrients is associated with the existence of new habitats favorable to the colonization of the macrofauna (MERLIM, 2005).

Table 2. Number of epiedaphic macrofauna individuals depending on months of the year in nine leguminous species grown in Aquidauana, MS

\begin{tabular}{lllllllllllll}
\hline Leguminous species & Aug & Sep & Oct & Nov & Dec & Jan & Feb & Mar & Apr & May & Jun & Jul \\
\hline Lepidoptera & 36 & 23 & 20 & 11 & 4 & 8 & 2 & 4 & 9 & 21 & 66 & 79 \\
Coleoptera & 93 & 91 & 94 & 172 & 61 & 35 & 13 & 41 & 42 & 47 & 80 & 74 \\
Orthoptera & 236 & 360 & 380 & 253 & 49 & 157 & 94 & 57 & 46 & 95 & 97 & 108 \\
Diptera & 38 & 20 & 0 & 34 & 25 & 30 & 12 & 11 & 32 & 15 & 17 & 17 \\
Blattaria & 72 & 97 & 197 & 149 & 36 & 119 & 46 & 27 & 25 & 31 & 21 & 24 \\
Hymenoptera & 72 & 250 & 150 & 437 & 94 & 91 & 36 & 248 & 57 & 70 & 72 & 51 \\
Isoptera & 12 & 14 & 0 & 20 & 7 & 29 & 39 & 12 & 6 & 16 & 51 & 581 \\
Hemiptera & 117 & 143 & 143 & 96 & 32 & 16 & 9 & 4 & 28 & 52 & 62 & 77 \\
Chilopoda & 4 & 5 & 19 & 11 & 11 & 6 & 0 & 2 & 2 & 1 & 3 & 3 \\
Diplopoda & 7 & 9 & 9 & 31 & 20 & 24 & 18 & 23 & 6 & 5 & 2 & 2 \\
Araneae & 8 & 23 & 0 & 42 & 28 & 25 & 15 & 21 & 10 & 17 & 25 & 14 \\
Scorpiones & 2 & 1 & 24 & 3 & 2 & 1 & 0 & 1 & 3 & 1 & 1 & 1 \\
Dermaptera & 0 & 0 & 0 & 0 & 0 & 3 & 1 & 0 & 0 & 0 & 0 & 0 \\
Oligochaeta & 0 & 0 & 0 & 0 & 0 & 0 & 0 & 0 & 0 & 0 & 0 & 0 \\
\hline Mean & 50 & 74 & 74 & 90 & 26 & 39 & 20 & 32 & 19 & 26 & 35 & 73 \\
\hline
\end{tabular}

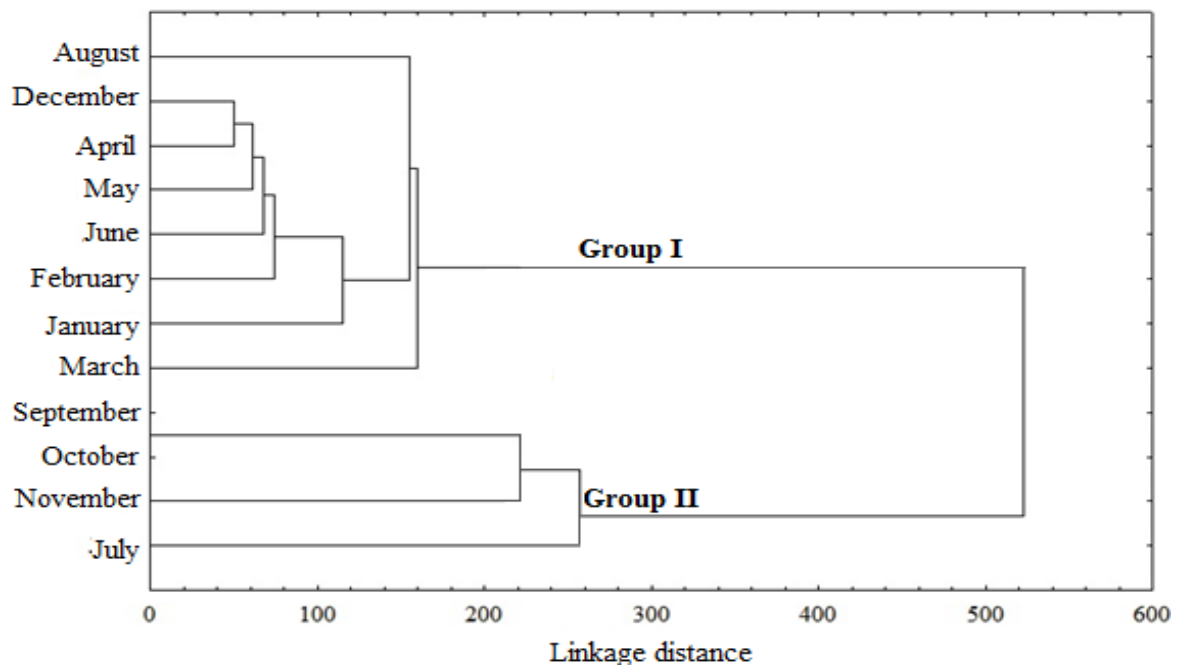

Figure 2. Cluster dendrogram between the months of the year based on the number of epiedaphic macrofauna individuals in Aquidauana MS

The other months of the year formed group 1 , indicating that the climatic conditions of the region in this period did not significantly affect the distribution of macrofauna epiedaphic individuals. According to Moço et al. (2005), the occurrence of these individuals is associated with the relationship 
amongst the species. The diversity of soil fauna may also be related to other factors, such as the plant density of the crops involved, adaptability to crop, food availability and content of the soil organic matter (KLADIVKO, 2001; SILVA et al., 2006).

\section{CONCLUSIONS}

The occurrence of epiedaphic macrofauna in the Cerrado/Pantanal ecotone region depends on the species of cultivated green manure and the time of year.
Mucuna pruriens was the species with higher occurrence of epiedaphic macrofauna, especially the Orthoptera and Hymenoptera. Cajanus cajan cv "fava larga" was the species most common between the individuals from Isoptera.

The months of September, October, November and July recorded the highest average for the number of individuals of epiedaphic macrofauna.

RESUMO: O objetivo deste trabalho foi verificar a similaridade entre nove espécies de adubo verde quanto à ocorrência de macrofauna epiedáfica. O experimento foi conduzido durante os meses de agosto de 2014 a julho de 2015 no setor de Fitotecnia da Universidade Estadual de Mato Grosso do Sul, Unidade de Aquidauana. Os tratamentos avaliados foram: Canavalia ensiformes, Dolichos lablab, Mucuna pruriens, Mucuna aterrima, Crotalaria spectabilis, Crotalaria juncea, Crotalaria ochroleuca, Cajanus cajan, Cajanus cajan e duas testemunhas (área de pousio e mata nativa). O delineamento experimental utilizado foi o inteiramente casualizado, com duas repetições. Cada parcela foi composta por 10 linhas com 4,5 m de comprimento. A macrofauna epiedáfica, que habita na interfase entre a cobertura vegetal e a superfície do solo foi coletada semanalmente por meio de armadilhas modelo Pitfall (de queda). Os indivíduos coletados em todas as espécies de adubação verde no mesmo mês foram somados e submetidos à análise de agrupamento. Os meses de setembro e outubro compuseram o grupo 2 devido as maiores médias de indivíduos da macrofauna epiedáfica. $\mathrm{O}$ mês de julho obteve o maior número de indivíduos da ordem Isoptera, compondo o grupo 3. O mês de novembro foi no qual foi coletado o maior número de indivíduos da ordem Hymenoptera, o que alocou este mês no grupo 4. Os demais meses do ano formaram o grupo 1 , o que indica que as condições climáticas da região neste período não afetam significativamente a distribuição dos indivíduos da macrofauna epiedáfica.

PALAVRAS-CHAVE: Análise de agrupamento. Pitfall. Variabilidade temporal.

\section{REFERENCES}

ALMEIDA, D. O. Fauna epiedáfica e atributos microbiológicos de solos sob sistemas de manejo no subtrópico brasileiro. 95p. Tese (Doutorado em Ciência do Solo). Universidade Federal do Rio Grande do Sul, Porto Alegre, 2012.

ASSAD, M. L. L.; LACERDA, R. C. A. Caracterização de termiteiros em área de pastagem do Distrito Federal. In: CONGRESSO BRASILEIRO DE CIÊNCIA DO SOLO, 25., 1995, Viçosa, MG. Resumos... Viçosa, MG: Sociedade Brasileira de Ciência do Solo; UFV, 1995. p. 445-447.

BARETTA, D. Fauna do solo e outros atributos edáficos como indicadores da qualidade ambiental em áreas com Araucaria angustifolia no Estado de São Paulo. 158p. Tese (Doutorado em Solos e Nutrição de Plantas) - Escola Superior de Agricultura "Luiz de Queiroz", Universidade de São Paulo, Piracicaba, 2007.

BARROS, E.; NEVES, A.; BLANCHART, E.; FERNANDES, E. C. M.; WANDELLI, E.; LAVELLE, P. Development of the soil macrofauna community under silvopastoral and agrosilvicultural systems in Amazonia. Pedobiologia, Amsterdã, v. 47, p. 273-280, 2003.

BLANCHART, E.; VILLENAVE, C.; VIALLATOUX, A.; BARTHÈS, B.; GIRARDIN, C.; AZONTONDE, A.; FELLER, C. Long-term effect of a legume cover crop (Mucunapruriens var. utilis) on the communities of soil macrofauna and nematofauna, under maize cultivation, in Southern Benin. European Journal of Soil Biology, Amsterdã, v. 42, p. 136-144, 2006. 
BUZINARO, T. N.; BARBOSA, J. C.; NAHAS, E. Atividade microbiana do solo em pomar de laranja em resposta ao cultivo de adubos verdes. Revista Brasileira de Fruticultura, Jaboticabal, v. 31, n. 2, p. 408-415, 2009.

DELARMELINDA, E. A.; SAMPAIO, F. A. R.; DIAS, J .R. M.; TAVELLA, L. B.; SILVA, J. S. Adubação verde e alterações nas características químicas de um Cambissolo na região de Ji Paraná-RO. Acta Amazônica, Manaus, v. 40, n. 3, p. 625 - 628, 2010. https://doi.org/10.1590/S0044-59672010000300024

EVERITT, B. S.; DUNN, G. Applied multivariate analysis. London: Edward Arnold, 1991. 400p.

KLADIVKO, E. J. Tillage systems and soil ecology. Soil and Tillage Research, Amsterdã, v. 61, p. 61-76, 2001.

LAVELLE, P. Assessing the abundance and role of invertebrate communities in tropical soils: aims and methods. Journal of African Zoology, Bloemfontein, v. 102, p. 275-283, 1988.

LAVELLE, P.; BIGNELL, D.; LEPAGE, M.; WOLTERS, V.; ROGER, P.; INESON, P.; HEAL, O. W.; DHILLION, S.Soil function in a cganging word: the role of invertebrate ecosystem engineers. European Journal of Soil Biology, Amsterdã, v. 33, p. 159-193, 1997.

LAVELLE, P.; SPAIN, A.V. Soil ecology. Dordrecht: Kluwer Academic, 2001. https://doi.org/10.1007/97894-017-5279-4

MERLIM, A. O. Soil macrofauna in cover crops of figs grown under organic management. Scientia Agrícola, Piracicaba, v. 62, n. 1, p. 57-61, 2005. https://doi.org/10.1590/S0103-90162005000100011

MARASAS, M. E.; SARANDÓN, S. J.; CICCHINO, A. C. Changes in soil arthropod functional group in a wheat crop under convencional and no tillage systems in Argentina. Applied Soil Ecology, Amsterdã, v. 18, p. 61-68, 2001.

MOÇO, M. K. S.; GAMA-RODRIGUES, E. F.; GAMARODRIGUES, A. C.; CORREIA, M. E. F. Caracterização da fauna edáfica em diferentes coberturas vegetais na região norte fluminense. Revista Brasileira de Ciência do Solo, Viçosa, v. 29, n. 4, p. 555-564, 2005.

OLIVEIRA, O. C. de; OLIVEIRA, I. P. de; ALVES, B. J. R.; URQUIAGA, S.; BODDEY, R. M. Chemical and biological indicators of decline/degradation of Brachiaria pastures in the Brazilian Cerrado. Agriculture, Ecosystems and Environment, Amsterdã, v. 103, p. 289-300, 2004.

PANIZZI, A. R.; PARRA, J. R.; Bioecologia e nutrição de insetos. Ed. EMBRAPA, Brasília, DF, 2009, cap. 9pág. 323.

PARRA, J. R. P.; PANIZZI, A. R.; HADDAD, M. L. Índices nutricionais para medir consumo e utilização de alimentos por insetos. In: PANIZZI, A. R.; PARRA, J. R. P. Bioecologia e nutrição de insetos - base para o manejo integrado de pragas. 1 ed. Brasília: EMBRAPA, p. 21-79, 2009.

SILVA, R. F.; AQUINO, A. M.; MERCANTE, F. M.; GUIMARÃES, M. F. Macrofauna invertebrada do solo sob diferentes sistemas de produção em Latossolo da região do Cerrado. Pesquisa Agropecuária Brasileira, Brasília, v. 41, n. 4, p. 697- 704, 2006. https://doi.org/10.1590/S0100-204X2006000400022

STATSOFT, INC. 2005. Statistica (data analysis software system). Version 7.1. Disponívelem: <www.statsoft.com>. Acesso em: 01/09/2015.

SWIFT, M. J.; HEAL, O. W.; ANDERSON, J. M. Decomposition in Terrestrial Ecosystems. Vol. 5, University of California Press, Berkeley, 1979. 219 p. 